\title{
Orígenes del Cristianismo: Memoria para una reforma de la Iglesia
}

\author{
Pablo Richard*
}

Recibido: Julio 2011 • Aceptado: Setiembre 2011

RESUMEN

El presente ensayo se propone reconstruir los orígenes del cristianismo en sus primeros 500 años, como propuesta para una futura reforma de la Iglesia Católica. En esta reconstrucción es necesario entender a Jesús en su plena humanidad e incluir los cristianismos disidentes, perdidos o marginados. El trabajo contiene tres partes: a. Memoria de los orígenes del cristianismo; b. Reforma y contra-reforma en la Iglesia Católica; y c. Los orígenes como memoria, credo y canon para una reforma actual de la Iglesia. Termina el autor advirtiendo sobre la necesidad de superar el vacío profético actual y caminar hacia un reforma de la Iglesia.

Palabras clave: Orígenes del cristianismo. Reforma y contra-reforma de la Iglesia. Movimiento de Jesús. Teología de la liberación. Comunidades eclesiales de base. Canon. Cristianismos disidentes. Evangelios, Gnosis. Sacro imperio romano cristiano.

\section{ABSTRACT}

In this essay it is proposed to rebuild all the origins of Christianity in its first 500 years, as a proposal for a future reform of the Catholic Church. During the reconstruction, it is necessary to recognize Jesus in his full humankind and include dissenting, lost, and marginalized Christians. The work contains three parts: a. Memory of the Origins of the Christianity; b. reform and counter-reform in the Catholic Church; and c. The origins as memory, creed, and canon for a current reform of the church. The author ends advising over the necessity of overcoming the prophetic empty current and walking toward a reform of the church.

Key words: Origins of Christianity. Reform and counter-reform of the church. Jesus' movement. Theology of the Liberation. Ecclesiastic's communities of base. Canon. Dissenting Christians. Gospels, Gnosis. Sacred roman Christian empire.

* Licenciado en Teología por la Universidad Católica de Chile. Licenciado en Sagradas Escrituras por el Pontificio Instituto Bíblico de Roma. Estudios en Arqueología bíblica de la Escuela Bíblica de Jerusalén. Doctor en Sociología de la Religión por la Sorbona, París. Ha sido profesor catedrático de la Universidad Nacional e investigador y responsable de Formación del Departamento Ecuménico de Investigaciones (DEI), San José, Costa Rica. 


\section{Introducción}

Lo más importante de este trabajo ha sido la reconstrucción de los orígenes del Cristianismo. Aproximadamente, sus primeros 500 años. Es una historia que comienza con el Movimiento de Jesús y que termina con la formación del Imperio Romano Cristiano. Esta transformación del Cristianismo en Imperio significó un fracaso para el Movimiento de Jesús. El Sumo Pontífice en la Iglesia Católica llegó a representar la figura del Emperador Romano, muy distante a la persona de Pedro, humilde pescador de Galilea. Pero el Movimiento de Jesús ha seguido vivo hasta la actualidad, gracias a las sucesivas reformas de la Iglesia. En todas las reformas más profundas y radicales de la Iglesia su modelo o canon ha sido esta memoria de sus orígenes.

La memoria de los orígenes ha permitido a la Iglesia recuperar su identidad como Movimiento Histórico de Jesús de Nazaret. Los primeros 4 Concilios Ecuménicos (en Nicea, Constantinopla, Éfeso y Calcedonia en los siglos IV y V) crearon una ortodoxia que se ha mantenido hasta la actualidad, y que ha finalmente sustituido a los 4 Evangelios.

La reforma de la Iglesia propuesta por Lutero $(1483$ - 1546) fue rechazada por la Iglesia Católica en el Concilio de Trento (1545 - 1563).
Esto sumergió a la Iglesia en 400 años de contra-reforma que, entre otros cánones, prohibió la traducción de la Biblia en lenguas nativas. La Iglesia Católica vivió 400 años sin las Sagradas Escrituras. En este tiempo la palabra "libertad" no se usó nunca.

El Concilio Vaticano II, (19621965) y las Conferencias Episcopales Latinoamericanas en Medellín (1968), Puebla (1979) y Aparecida (2007) reconstruyeron la identidad perdida de la Iglesia como Movimiento de Jesús en la actualidad. En esta tarea fue muy importante la Teología de la Liberación y las Comunidades Eclesiales de Base.

Ahora que la Iglesia Católica ha comenzado otra vez a "caminar hacia atrás" y a perder su "vocación profética", es urgente reconstruir un futuro con esperanza. Esto es posible si somos capaces de realizar una profunda reforma de la Iglesia a la manera del Movimiento de Jesús. En este artículo hemos buscado fundamentalmente unir Memoria, Credo y Canon para esta reforma necesaria de la Iglesia.

\section{Memoria de los orígenes del Cristianismo}

Jesús de Nazaret está en la raíz de los orígenes del cristianismo, pero ¿quién era este Jesús antes del cristianismo? Un Jesús que no se predicó a sí mismo, sino 
al Reino de Dios. Un Jesús que nunca definió qué era ese Reino, sino simplemente lo practicó y los evangelios lo narraron.

La praxis de Jesús y su concepción del Reino no habrían sido posibles sin una imagen de Dios totalmente diferente. No podemos deducir algo acerca de Jesús partiendo de lo que creemos saber acerca de Dios (Nolan, 1996 y Sobrino, 1997).

Solo podemos entender a Jesús a partir de su plena humanidad. No es Dios el que nos revela a Jesús. Es Jesús el que nos revela a Dios. Tanto en la cruz como en la resurrección Jesús nos reveló su condición humana. Jesús murió en la cruz como un fracasado y abandonado de Dios. Jesús pudo haber descendido vivo de la cruz y su Padre igualmente pudo haberlo salvado de esta. Nos sentimos también frustrados porque Jesús resucitado es un fantasma irrelevante, que no muestra algún poder para hacer real el Reino de Dios.

La respuesta a estas aserciones la encontramos cuando vemos a Jesús a partir de su plena humanidad. Jesús no descendió de la cruz, ni su Padre lo salvó de la crucifixión, para hacer visible a nuestros ojos que Jesús moría comocualquier hombre condenado a muerte. Jesús, con todo su poder, no se liberó de la cruz por fidelidad a su condición humana. Murió como todos los sentenciados a muerte por la ley romana.
Igualmente en su resurrección, Jesús pudo presentarse corporalmente y con poder ante el Sanedrín, ante el sumo sacerdote y ante Pilato, para probar con esa manifestación de poder su divinidad. Jesús no lo hizo, igualmente por fidelidad a su condición humana. Jesús resucitado no hizo ninguna demostración de poder; por eso solo se apareció a unas mujeres y a unos discípulos poseídos por el miedo.

Jesús murió y resucitó sin traicionar su condición plenamente humana. Unir "divinidad" y "poder" era una tentación que Jesús rechazó. El Imperio Romano Cristiano a partir del siglo IV cayó en esa tentación. También hoy la Iglesia fracasa cuando usa el "poder sagrado" para imponerse en la sociedad.

\section{Una memoria sin exclusiones}

El cristianismo nace como tradición oral, pero cuando ésta empieza a ser incontrolable, se impone la necesidad de seleccionar escritos que sean normativos ("canónicos") para las comunidades. El primer esbozo de canon bíblico está en el código de Muratori (fines siglo II) y el cierre definitivo del Canon fue establecido por Atanasio de Alejandría el año 367. Coincide con el Canon hoy vigente en toda la Iglesia. Antes de que se diera esta definición del canon bíblico no podemos diferenciar nítidamente entre escritos 
canónicos y no canónicos, por la sencilla razón de que todavía no existe un Canon para hacer la diferencia. Casi todas las fuentes existentes, "canónicas" y "no-canónicas", pueden ser, a su manera, legítimas para la reconstrucción del Movimiento histórico de Jesús. Antes del canon el límite entre ortodoxia y herejía es aún confuso. En los libros canónicos hay contradicciones, ausencias y pseudo-epigrafías. En los no-canónicos, por otro lado, hay tradiciones auténticas y necesarias.

En los orígenes del cristianismo podemos tomar en cuenta alrededor de 46 documentos, de los cuales solo 27 están incluidos en el Canon del NT. Tomar el Canon del NT como única fuente, se corre el riesgo de ignorar dos siglos de una tradición mayor y plural, y construir el Movimiento de Jesús sobre una base ya institucionalizada por la misma Iglesia.

\section{No excluir los cristianismos disidentes, perdidos o marginados}

No excluir de la memoria del Movimiento histórico de Jesús los movimientos así llamados "herejes", como tampoco los "cristianismos perdidos" o "marginados". Importante también es escuchar la crítica al cristianismo de algunos filósofos no-cristianos (como Celso, Porfirio y Juliano).
Una visión histórica falsa es ver las "herejías" solo como un "problema", una "desviación", un "error" o un "peligro" para las Iglesias. La destrucción de los escritos de los "herejes", de su memoria, y muchas veces de sus vidas, ha sido negativa para la memoria del Movimiento Histórico de Jesús. En los cristianismos perdidos o marginados siempre hay algo de verdad, y en los escritos canónicos también hay contradicciones y lagunas. El Canon, por lo tanto, nos ayuda para un discernimiento positivo de la tradición.

\section{Primera generación cristiana" (años 30 - 70)}

Es la tradición de los discípulos y discípulas inmediatos de Jesús. Un tiempo donde predomina la tradición oral sobre la escrita. Es la tradición propia de los pobres y excluidos.

En los comienzos del cristianismo hay seis tradiciones originales e independientes unas de otras, identificadas con 6 nombres: Pablo, Marcos, Juan, Santiago, Tomás y María Magdalena. Las 7 cartas auténticas de Pablo de Tarso, el Evangelio de Marcos, el Evangelio de Juan y la carta de Santiago fueron incluidos en el Canon ya antes de los años 70. El Evangelio de Tomás y de María Magdalena quedaron fuera del Canon. La tradición de 
Juan y María Magdalena son escritos posteriores, pero desde los inicios del movimiento de Jesús están ya inicialmente presentes en su tradición oral y parcialmente ya escrita. Los escritos canónicos están a la mano y los conocemos. Voy a citar algunas frases de esos evangelios no-canónicos, simplemente para sentir su presencia.

\section{El Evangelio de Tomás, Dídimo, el mellizo de Jesús}

El original griego de este Evangelio (EvTo) nos remonta al siglo primero. Tuvo varias traducciones y su estilo no es narrativo sino sapiencial. Posee ambigüedades, pero en general hace memoria de las palabras más antiguas de Jesús y las recuerda posteriormente en el conflicto con la gran Iglesia. El Evangelio original, en todo o en parte, antecede a los Sinópticos. El Evangelio de Juan es posterior a este Evangelio, y podría ser una respuesta a él.

En la redacción del EvTo habría dos estratos. Uno antiguo, ortodoxo, quizás contemporáneo del Evangelio de Marcos, sin influjo de la gnosis posterior y aceptado por la Iglesia. Más tarde, la gnosis cristiana hace una relectura del Evangelio de Tomás para confrontar, con palabras deformadas de Jesús, su enfrentamiento con la gran Iglesia.
Evangelio de María (Magdalena)

La versión original griega de este Evangelio es de mediados del siglo II.

Cito solo una frase:

"Leví habló y dijo a Pedro: Pedro, siempre fuiste impulsivo. Ahora te veo enfrentando contra una mujer (María Magdalena) como si fuera un adversario. Sin embargo, si el Salvador la hizo digna, ¿quién eres tú para rechazarla? Bien cierto es que el Salvador la conoce perfectamente; por esto la amó más que a nosotros. Más bien, pues, avergoncémonos y revistámonos del hombre perfecto, partamos tal como nos lo ordenó y prediquemos el Evangelio, sin establecer otro precepto ni otra ley fuera de lo que dijo el Salvador. Luego que [Leví hubo dicho estas palabras], se pusieron en camino para anunciar y predicar".

\section{La segunda generación cristiana (años 70 - 135)}

Es la generación de los discípulos y discípulas de los que fueron discípulos y discípulas de Jesús. En esta época aparecen diferentes documentos que mantienen viva la tradición de los orígenes del Movimiento Histórico de Jesús:

- La Tradición de los Evangelios canónicos y no-canónicos 
- Los Testimonios directos de vida de las comunidades en este período, $\mathrm{y}$

- Las Leyendas populares muy difundidas en el Pueblo de Dios.

\section{Tradición de los Evangelios}

En esta época hay dos Evangelios canónicos: el Evangelio según Mateo y el Evangelio según Lucas y los Hechos de los Apóstoles, unido al Evangelio en una sola obra.

El Evangelio de Mateo ha sido el Evangelio más comentado en la historia de la Iglesia, debido a la interpretación demasiado eclesiológica que se ha hecho de él. Especialmente, de aquella frase de Jesús: "Tú eres Pedro y sobre esta piedra edificaré mi Iglesia" $(16,18)$, que se convirtió en el canon dentro del canon del Nuevo Testamento. Este libro fue escrito en la ciudad de Antioquía en los años ochenta.

\section{Evangelio de Lucas y Hechos de los Apóstoles}

Redactados posiblemente en Éfeso, hacia el año 85. En la teología de Lucas el centro es Jerusalén. Hay un camino de Galilea a Jerusalén (Evangelio) y de Jerusalén a Roma (Hechos de los Apóstoles). El cristianismo es presentado como un camino, lleno de obstáculos y muros. Según Lucas, la función del Espíritu Santo es romper esos muros, para que entren muchos pueblos en ese camino de la Iglesia. La ruptura de esos muros abrió el movimiento de Jesús a todos los pueblos, con sus tradiciones culturales y religiosas propias.

\section{Evangelios no canónicos}

Que no entraron en el Canon, pero que también son importantes para reconstruir los orígenes del Cristianismo:

- Evangelio de los Nazarenos Toma como base el Evangelio de Mateo, pero lo aumenta con paráfrasis que a veces aportan detalles importantes a dicho Evangelio.

Compuesto en Siria, mediados del siglo II, donde había una comunidad judeocristiana cuyo libro sagrado era el Evangelio de Mateo. Los Padres de la Iglesia nunca le achacaron desviaciones heréticas.

- Evangelio de los Apóstoles

No se trata del Evangelio de Mateo abreviado, sino de una refundición de material tradicional, especialmente con los milagros de Jesús. "Es un ejemplo de literatura popular no oficial". Muestra influjo de Juan. Una de sus fuentes es el Pastor de Hermas (que ya veremos). Está dirigida a las Iglesias del 
Oriente y del Occidente, del Norte y del Sur, y salió a la luz en Asia Menor o en Egipto. Su composición se fija entre el 130 y el 140. El relato de la Resurrección en este Evangelio es una combinación de los cuatro Evangelios canónicos.

- Un Evangelio anónimo (conocido como "Papiro Egerton 2") Mezcla material de estilo sinóptico con fraseología del Evangelio de Juan. Es una pieza independiente de la tradición. Una composición de memoria a partir de la tradición oral. El papiro 2 es un texto de mediados del siglo II que nos revela un estadio fluido de la tradición: por una parte, existen ya tradiciones escritas sobre Jesús; por otra parte, no son suficientemente canónicas, y por eso pueden ser acortadas o transformadas. El autor del texto cita de memoria los cuatro Evangelios. Hay, además, influencias de una reelaboración oral de la tradición.

- Evangelio de Felipe

Este Evangelio no entró en el canon, pero no por eso es hereje o apócrifo. Es una obra catequética, escrita a fines del siglo II o comienzos del III. Valora la figura de María Magdalena como compañera de Jesús y la identidad cristiana en un mundo que le era hostil.

Si dices "soy judio", nadie se preocupará;

si dices "soy romano", nadie se inquietará;

si dices "soy griego, bárbaro, esclavo o libre”, nadie se perturbará.

[Pero si dices] "soy cristiano", [todo el mundo] temblará.

(Evangelio de Felipe: ${ }^{\circ} 49$ )

\section{Testimonios de vida de las comunidades (años 70 - 135)}

\section{Apocalipsis}

Resistencia al Imperio Romano (Asia Menor, años 90-96)

Este libro nos presenta la práctica del Movimiento de Jesús en su enfrentamiento con el Imperio Romano, posiblemente bajo Domiciano entre los años 90 y 96. Para los cristianos, el poder del Emperador viene de Satanás y por eso el emperador es Bestia. El falso Profeta, seduce a todos para que adoren a la Bestia. Roma es una prostituta que se emborracha con la sangre de los mártires de Jesús. El autor no es un apocalíptico perdido en descripciones fantásticas, sino un teólogo que conoce muy bien, la realidad y propone una práctica de resistencia a los cristianos de su época. Es un libro liberador y su utopía es histórica y política. No es un libro confuso 
y de terror, que habla nada más de catástrofes, juicios y castigos.

El Apocalipsis se expresa mediante mitos y símbolos. El mito es histórico, reconstruye la conciencia colectiva y la praxis social del Pueblo de Dios. El Apocalipsis crea mitos liberadores y subvierte los mitos dominantes.

\section{La Didajé o Doctrina}

de los Doce Apóstoles:

Siria, hacia los años 100-110

Es como un manual de la comunidad. Brinda puntos de vista diferentes de las prácticas de la Iglesia en sus orígenes. Contiene proverbios, catequesis, oraciones y normas de vida. Afirma una jerarquía itinerante de apóstoles, profetas y doctores.

"Concerniente a los apóstoles y profetas, actúa con ellos de acuerdo con la doctrina del Evangelio. Cuando el apóstol se vaya que no tome nada consigo, sino es pan hasta su nuevo alojamiento. Si pide dinero, es un falso profeta. Por el modo de vida se distinguirá el verdadero profeta del falso. Cada profeta que enseñe la verdad, si no la practica, es un falso profeta. El que dice en espíritu: dame dinero, o cualquier otra cosa, no le presten oído. En cambio si dice que se dé a otros necesitados, nadie lo juzgue. Elíjanse obispos y diáconos dignos del Señor, hombres mansos, no amantes del dinero, sinceros y probados; porque también ellos les sirven a ustedes en el ministerio de los profetas y maestros". (cita)

Pastor de Hermas: Roma, hacia el año 100

Hermas es un esclavo liberto que vivió en Roma en la era apostólica, después de la destrucción del Templo en el año 70. El texto evidencia que no ignora la tradición oral sobre Jesús de Nazaret en las comunidades. Usa sentencias breves. En él se encuentra en forma embrionaria lo que más tarde sería codificado en el NT. El libro es una alegoría que expresa la esperanza apocalíptica viva en la comunidad de los pobres en Roma.

Hermas es un hombre casado, padre de familia, que compone un texto cristiano de gran envergadura, leído en muchas comunidades durante más de un siglo. Hermas vive las exigencias radicales de Jesús en la vida cotidiana. No es un texto dogmático. Es importante para conocer, en los orígenes del cristianismo, esa otra corriente anti-jerárquica y anti-burocrática que contrasta con la corriente tradicionalista y sacerdotal. El Pastor de Hermas es durísimo con los presbíteros y diáconos, así como con los jefes de la Iglesia que buscan los primeros puestos.

"¿Puede un Espíritu divino recibir dinero y profetizar? No 
es posible que un profeta de Dios haga esto". (cita)

"En Arcadia (su tierra) moran los dioses defensores de la naturaleza. Alli late la vida sana y natural, lejos de los templos donde se acumulan grupos de sacerdotes a la hora del culto. Yo había aprendido que Dios huye de los templos, gusta del aire libre y prefiere revelarse en la naturaleza. En Roma me siento empequeñecido en medio de tantas personas hostiles a nuestro movimiento. Roma es de los emperadores, de los senadores y patricios. Aqui estoy en Arcadia, cerca de mis raíces." (cita)

"Todo esto me dejó con el deseo de profundizar más las cosas. ¿A quién recurrir? ¿A los presbiteros? Ellos dicen siempre lo mismo, todo les parece demasiado fácil. Repiten lo que está en los libros. Decidi entonces no seguir ese camino”. (cita)

\section{Leyendas populares}

No están en el canon bíblico, pero la fe del pueblo sencillo siempre busca lo que no encuentra en los escritos canónicos. Los apócrifos narran el "Jesús real". En todo caso, es legítimo utilizar esa literatura no-canónica para reconstruir el movimiento histórico de Jesús. Esta literatura es enorme, aquí solo presentamos dos ejemplos muy resumidos:
Los Hechos de Pedro

Fueron compuestos hacia el año 190. Narra el martirio de Pedro. Cuando este se sintió presionado a abandonar Roma, encontró a Jesús. Y cuando le vio, le dijo: “¿Adónde vas, Señor?" ¿¿Quo vadis, Domine?]. Y el Señor le replicó: "Voy a Roma a ser crucificado". "Señor -le dijo Pedro-, ¿vas a ser crucificado otra vez?". Y Él le respondió: "Sí, Pedro, voy a ser crucificado otra vez". Cayó entonces Pedro en la cuenta y volvió a Roma, lleno de regocijo y glorificando al Señor porque este había dicho: "Voy a ser crucificado de nuevo", que es lo que estaba a punto de suceder a Pedro, el cual pronto fue crucificado cabeza abajo.

\section{La vida de María,} la madre de Jesús

Documento muy extenso y popular, que contiene narraciones y creencias hoy aceptadas por la Iglesia. Muchas tradiciones sobre María la madre de Jesús están en estos libros populares no canónicos y no en los escritos canónicos. Así por ejemplo la doctrina sobre la dormición y asunción de María. 


\section{Tradiciones teológicas institucionales contrapuestas (años 135 - 300)}

Los cristianismos perdidos:

Marción (100-160) y el marcionismo

Marción nace hacia el año 100. Perteneció a la comunidad cristiana de Roma. Era un hombre rico. El año 140 es expulsado de su comunidad y funda una Iglesia propia que conocería una gran expansión. Muere en el año 160. Marción no pretendía fundar una Iglesia, ni ser profeta, sino un predicador del mensaje genuino y originario de Jesús, que según él había sido deformado por la Iglesia de su tiempo.

Marción, excomulgado en Roma, se fue al Asia Menor donde tuvo un éxito extraordinario. Fundó Iglesias donde quiera que iba. La Iglesia Marcionita, según testimonio de Justiniano (150), "se difundió hasta los confines de la tierra”. En Occidente, las Iglesias marcionitas mantuvieron su influjo hasta finales del siglo III, y en Oriente, principalmente en las regiones de habla siríaca, hasta el 450.

¿Por qué Marción y el marcionismo tuvieron tanto éxito? Porque buscaba rescatar la memoria del Evangelio de Jesús, que la Iglesia habría deformado y olvidado. El problema fue su literalismo y fundamentalismo. En todo caso, es uno de esos "cristianismos perdidos" que es importante incorporar a la memoria del Movimiento histórico de Jesús y a la Iglesia.

Montano y el montanismo (fines del siglo II)

Montano nació en Frigia, Asia Menor, y empezó su actividad hacia finales del siglo II. Parece que escribió muchas obras; sin embargo nada se conservó. No es ya posible escuchar su propia voz, porque su pensamiento y sus escritos fueron aniquilados.

Podemos ver el montanismo desde tres perspectivas distintas (Frangiotti, 1995).

- Como una tentativa de retorno a la Iglesia de los orígenes y de reforma de la Iglesia, contra un episcopado que sofocaba los movimientos proféticos y carismáticos.

- Como un movimiento político religioso de protesta de las zonas rurales de Frigia contra las iglesias urbanas dominadas por sus obispos.

- Como reacción de un conservadurismo rural contra las iglesias en proceso creciente de helenización. Posiblemente estas cuatro perspectivas tiene cada una algo de histórico. 
En el campo dogmático, Montano se mantuvo dentro de la ortodoxia. Contra el gnosticismo afirmaba la resurrección en la carne. El movimiento tuvo gran difusión en Oriente y en Occidente, incluso dentro de la Iglesia. El año 207 un teólogo muy apreciado, Tertuliano, se integró al montanismo. El mensaje central de Montano sobre la acción del Espíritu Santo y la reforma de la Iglesia pervivieron en la historia, en cierto sentido hasta hoy.

Gnosis, gnósticos y gnosticismo: lo positivo y lo negativo

El gnosticismo fue el movimiento social y teológico más difundido y atractivo hasta el siglo V. Ejerció una atracción especial entre la gente culta, por su valoración de las ciencias y las filosofías. Los gnósticos cristianos imprimieron un nuevo carácter a la teología cristiana para que fuese mejor aceptada por la cultura helenista.

La gnosis, como teoría del conocimiento, deja de lado la voluntad, el sentimiento y la imaginación. El gnóstico es un intelectual puro.El gnosticismo encierra un profundo desprecio por la materia y por la corporeidad humana.Los gnósticos objetan a los ortodoxos el tener un Dios pequeño, mezquino y arrogante. Su Dios, en cambio, es "mayor".
Contra los gnósticos dualistas, que despreciaban la materia y la corporeidad humana, Tertuliano enfatizaba que Jesús resucitó en "esta carne, bañada con sangre, construida con huesos, entretejida con nervios, entrelazada con venas; una carne que nace y muere, indudablemente humana".

\section{Los maestros cristianos}

El siglo II es fundamental en la evolución del cristianismo a causa de la férrea lucha por el control de la Palabra de Dios, entre los presbíteros (pastores, obispos) y los maestros (doctores, profetas). Los maestros constituyen la fuente de energía de la cultura cristiana en los siglos II y III. En Roma hay importantes agrupamientos en torno a célebres maestros como Hermas, Valentín, Taciano y Justino. En Cesarea de Palestina actúa el famoso Orígenes, en la primera parte del siglo III.

En síntesis: Los documentos citados representan la "otra cara del cristianismo", los "cristianismos perdidos" y los "maestros cristianos" malinterpretados, perseguidos, ignorados y silenciados. Se reconstruyó una historia de la Iglesia y de la teología donde estos movimientos no existen.

Surge una pregunta fundamental: ¿por qué estos movimientos, a 
pesar de ser perseguidos y silenciados, alcanzaron tanto éxito, especialmente (con excepciones) entre grupos cristianos socialmente marginados o entre cristianos cultos marginados por sus ideas? En todo caso, no podemos reconstruir la memoria del "Movimiento de Jesús" si no reconstruimos la memoria de todos esos cristianismos perdidos, de sus teologías y sus maestros.

\section{Críticas de filósofos no- cristianos al cristianismo (Celso, Porfirio, Juliano)}

Citamos a Celso: "Discurso verdadero contra los cristianos" (año 178)

La crítica de Celso al cristianismo es la crítica de un filósofo culto, integrado a la ideología y religión del Imperio Romano, que conoce bien el cristianismo y las Sagradas Escrituras. Celso hace visible la situación histórica real de los cristianos: "son ignorantes, incultos y simples de espíritu, esclavos, mujeres pobres y niños", "no pueden persuadir más que a necios, plebeyos, estúpidos, esclavos, mujerzuelas y chiquillos". (cita) Celso termina su Discurso invitando a los cristianos a que abandonen su situación marginal y colaboren con las fuerzas organizadas del Imperio contra la barbarie. Exige a los cristianos que "apoyen al emperador y lo ayuden en la defensa del derecho". (cita)
Algunos teólogos y apologistas

en el mundo greco-romano del siglo II

Justino, Galilea, muere mártir el año 165. Tertuliano, nace en Cartago en 170 (aproximadamente) y muere en 220. Ireneo de Lyon: 140-190 (fechas aproximadas).

Estos no buscan tanto responder a las críticas que los filósofos paganos hacían a los cristianos, cuanto ayudar a los cristianos conversos a vivir su fe en el mundo hostil que los acosaba. Al movimiento de Jesús se le acusaba de ser una secta que rehusaba dar culto al Emperador y a los dioses; por consiguiente, era una secta acusada de "ateísmo", peligrosa para el Estado. La respuesta de los apologistas no fue tanto teológica o doctrinal, sino en la creación de una "paideia cristiana", es decir, una nueva manera de vivir en el mundo hostil.

Evolución institucional en la Iglesia

Obispos y presbiteros en contradicción con profetas y maestros

Los ministerios carismáticos son por lo general itinerantes y misioneros, muy cercanos al movimiento de Jesús, con el entusiasmo propio de los que creen en la fuerza del Espíritu y en la proximidad 
del Reino de Dios. La tradición institucionalizada se basa en la distinción entre clérigos y laicos, la cual no existió en los dos primeros siglos de la Iglesia. El "orden de los presbíteros" se define fundamentalmente por su relación con el culto, por eso existe un proceso de "sacerdotalización" del clero.

\section{El Sacro Imperio Romano Cristiano}

Desde Constantino (306) hasta el fin de los cuatro concilios ecuménicos (451)

Desde Nerón (68) hasta Dioclesiano (303) hay un período de aproximadamente 230 años, que va desde la primera generación cristiana hasta el nacimiento del Sacro Imperio Romano Cristiano. La Iglesia vive todo este tiempo entre el martirio y su institucionalización interna.

La persecución de Diocleciano en el año 303 marca un punto culminante en la vida de la Iglesia. Hay un antes y un después. Fue la persecución más dura, larga y universal sufrida por el cristianismo en la Antigüedad.
Transformación del Imperio Romano en Imperio Cristiano: Constantino y Teodosio (306 al 395, aproximadamente)

La transformación de la Iglesia en un Imperio Cristiano, no es un triunfo para la Iglesia, sino su más profundo fracaso. Un "Imperio Cristiano" es exactamente lo opuesto al "Reino de Dios". Cuando el Imperio Romano se hace cristiano, la Iglesia se transforma en Imperio. El Movimiento de Jesús, sin embargo, no desaparece, sino que permanece vivo al interior del Sacro Imperio Romano Cristiano.

Los emperadores Diocleciano, Constantino y Teodosio tienen una misma estrategia política y teológica: utilizar la religión para lograr la unificación del Imperio, lo que implica una intervención creciente de los emperadores en los asuntos religiosos.

Diocleciano (284-305)

Utiliza la restauración del culto tradicional a los dioses imperiales, lo que lleva necesariamente a la destrucción del cristianismo como proyecto opuesto a los dioses. 
Constantino (306-337)

Utiliza al cristianismo para unificar el Imperio, para lo cual debe combatir a los herejes y a los dioses imperiales originarios.

Teodosio (346-395)

Declara finalmente el cristianismo religión oficial del Imperio, con lo cual el cristianismo se transforma en Sacro Imperio Romano Cristiano.

\section{Constantino: emperador "cristiano" de los romanos (306-337)}

Constantino se convierte y se bautiza como primer emperador cristiano de Roma en su lecho de muerte (año 337). Su madre era cristiana; no obstante, él se cría prácticamente entre soldados y rodeado de paganos.

En el año 313 Constantino publica el Edicto de Milán, que proclama la tolerancia del Estado con todas las religiones y devuelve a los cristianos los bienes que les habían arrebatado en las últimas persecuciones. Fuera del campo de la religión, Constantino ejerce una monarquía autocrática. Las medidas tomadas en este "edicto de tolerancia" eran "para utilidad y provecho del Estado". Se busca "enderezar todas las cosas conforme a las antiguas leyes y orden público de los romanos". (cita) Ahora pueden reconstruir sus templos, pues, los cristianos ya no atentan contra el orden público. Constantino vincula a los obispos con la administración del Estado y refunda sobre la antigua ciudad comercial de Bizancio, una nueva ciudad llamada "nueva Roma", y posteriormente Constantinopla (hoy Istambul), como capital de la verdadera fe. Constantino no solo levanta iglesias cristianas, sino también templos paganos. Con el paso de la persecución a la tolerancia, se da comienzo a un régimen de cristiandad.

Eusebio, obispo de Cesarea, historiador de la cristiandad (263-339)

Eusebio legitima y exalta el triunfo de Constantino como la posibilidad de construir en el presente una Iglesia triunfante, con poder religioso y político en toda la "oikumene" imperial. Para Eusebio, Constantino es un enviado escogido por Dios para salvar a la Iglesia de la persecución. "Fue el único entre todos los que tuvieron en su mano el poder romano, que era amigo de Dios y Soberano del universo". Su imperio es "imitación del poder monárquico del cielo", porque él mismo lo ha organizado según el modelo del gobierno celeste. 
Hilario de Poitiers tiene otra visión del Imperio "Cristiano" (315-368).

Citamos nada más un texto sobre el emperador Constancio (hijo de Constantino):

"Ahora debemos luchar contra el anti-Cristo...

Este no nos apuñala por las espaldas, sino que nos acaricia el vientre...

No confisca nuestros bienes,

sino que nos enriquece para la muerte...

No azota nuestras espaldas, sino que debilita nuestra alma con su oro...

Construye Iglesias para demoler la fe...

Tú distribuyes entre tus adictos sillas episcopales,

Re-emplazando los buenos por los malvados...

Tú logras ser perseguidor sin hacer mártires (citado en Marins, s. f.: 310ss. ).

\section{El emperador Teodosio I (346-395)}

Asume como Emperador en todo el territorio romano y promulga un nuevo edicto (año 380) que declara el cristianismo como religión oficial del Imperio.

\section{Carácter divino de los emperadores}

Diocleciano es el primer emperador que admite públicamente ser considerado y adorado como un dios. Ya en el paganismo, anterior al cristianismo, se forja una relación estrecha entre el Emperador y la Divinidad. El cristianismo, profundamente monoteísta, rechazaba la divinidad del emperador; sin embargo, lo consideraba representante de Dios en la tierra.

La ceremonia, la liturgia y el arte imperiales hacían visible esta divinización del Emperador. El ícono o imagen del Emperador estaba en todos los lugares públicos y su rostro aparecía como un rostro divino. La Iglesia imita las manifestaciones de poder y el ceremonial imperial imperante en el ámbito civil. El color púrpura era el color distintivo del Emperador y de su corte. Los cardenales son también los príncipes "purpurados" en la Iglesia Católica. El Papa asume el título imperial de "Sumo Pontífice". Por eso, al decir de un teólogo español actual: "el Papa se parece más a Constantino que a Pedro".

\section{Los obispos en el Sacro Imperio Romano Cristiano}

Constantino colma de privilegios a los cristianos y eleva a muchos obispos a puestos importantes, confiándoles tareas más propias de funcionarios civiles que de pastores de la Iglesia de Cristo.

Un testimonio: Gregorio Nacianceno (330-390) renuncia al 
episcopado en el concilio de Constantinopla (381) al ver con amargura el fausto de sus colegas:

"Yo ignoraba que nosotros tuviésemos que rivalizar con los cónsules, con los prefectos, con los generales más ilustres, que tuviésemos que ser llevados en caballos adornados lujosamente y porteados en literas con boato y pompa... Elegid otro obispo que sepa complacer a la masa; a mí dadme la soledad en el campo" (cita)

\section{Los cuatro concilios ecuménicos}

Fundamento dogmático político del Sacro Imperio Romano Cristiano

Primer Concilio Ecuménico:

Nicea, año 325

Segundo Concilio Ecuménico:

Constantinopla, año 381

Tercer Concilio Ecuménico:

Éfeso, año 431

Cuarto Concilio Ecuménico:

\section{Calcedonia, año 451}

(Los concilios son "ecuménicos" porque convocan a las Iglesias de todo el espacio habitado ("oikoumene") del Imperio.
Primer Concilio Ecuménico:

Nicea, año 325

Se hizo en el "palacio de Constantino", considerado "la morada de Dios en la tierra". Constantino convoca el concilio y preside la sesión inaugural, así como los debates en torno al problema políticodoctrinal. Es el Emperador el que envía a las Iglesias los resultados del concilio y confiere a los decretos conciliares la validez de ley del Estado ("dogmata"). Constantino actúa como cabeza del Sacro Imperio Cristiano y manipula definiciones dogmáticas para conseguir la unidad de la Iglesia. Su intencionalidad es más política que teológica.

Segundo Concilio Ecuménico: Constantinopla, año 381

El concilio logra la unidad teológica del Imperio Romano con la redacción definitiva del llamado: "Credo niceno-constantinopolitano", vigente hasta hoy.

La fórmula que se refiere al Jesús histórico dice: "se hizo hombre y fue crucificado". Solo se afirma que Jesús "nace y muere". Nada se dice de la vida histórica de Jesús entre su nacimiento y su muerte, 
tal como es narrada en los Evangelios. El concilio se sitúa más en la corriente dogmática que en la tradición bíblica. La historia de la Teología y de la Catequesis están enmarcadas por este credo.

Tercer Concilio Ecuménico: Éfeso, año 431

Triunfa el dogma de María como "Madre de Dios", y no la confesión de María como "Madre de Jesús". La tendencia es divinizar a María y negar la plena humanidad de Jesús.

\section{Cuarto Concilio Ecuménico: Calcedonia, año 451}

El concilio se presenta como interpretación de la fe de los tres concilios anteriores: Nicea, Constantinopla y Éfeso. Existe consenso sobre la unión inseparable del hombre con la divinidad, pero ahora se insiste "en la humanidad de Dios". Calcedonia puso el acento en la plena humanidad de Jesús y en María como madre de Jesús. Esto implicó un cisma en el mundo cristiano griego, cisma que perdura hasta hoy.

\section{Comentario general sobre los cuatro concilios}

En los cuatro primeros concilios se llega a un consenso sobre los dogmas referentes a Dios, la Trinidad, Jesús y la Iglesia. La filosofía griega y el condicionamiento político son un factor importante en la formulación de estos dogmas. Esa formulación fue quizás necesaria para superar la desarticulación y fragmentación de las tradiciones teológicas, a veces contradictorias, de la época. El problema es el abismo que nace entre definición dogmática y tradición bíblica de las Iglesias. La Iglesia continúa "encerrada" en los dogmas sobre Dios y Jesús, tal como aparecen estructurados en el Credo niceno-constantinopolitano, que confesamos en forma inmutable hasta el presente. Nace una contradicción entre dos tradiciones: una doctrinaria y otra bíblica. Son dos tradiciones paralelas que difícilmente convergen entre sí. El catecismo católico ha escogido la tradición doctrinaria, con algunas citas bíblicas aisladas. La reforma de la Iglesia, a lo largo de su historia, ha escogido en forma preferente la tradición bíblica. Por eso toda reforma de la Iglesia nace cuando "devolvemos" las Sagradas Escrituras al Pueblo de Dios.

Surge una pregunta
inquietante:

¿Sustituyeron los cuatro primeros concilios ecuménicos a los cuatro Evangelios? 


\section{Una visión de conjunto del Sacro Imperio Romano Cristiano}

(desde los años 300 d.C. hasta los años 600 d.C.).

Primero: los cristianos son cruelmente perseguidos en todo el Imperio (Diocleciano, año 303).

Segundo: los cristianos pasan de perseguidos a tolerados (Constantino: "Edicto de Milán sobre Libertad de cultos", año 313).

Tercero: los cristianos pasan de tolerados a privilegiados (Teodosio I: Decreto sobre el Cristianismo como religión oficial del Imperio, año 379).

Cuarto: la Iglesia utiliza el poder imperial para perseguir a los herejes y otros enemigos de la Iglesia (como lo hizo Ambrosio, Obispo de Milán: 340-397).

Quinto: la Iglesia y el Imperio Romano occidental concurren como dos poderes al mismo nivel (situación de hecho en los años 400).

Sexto: la Iglesia se impone sobre el Imperio Romano occidental. El Papa llega a ser la máxima autoridad en la capital del Imperio Romano (como ejemplo: León Magno, Papa en Roma entre los años
440-461: concepción monárquica del Papa que busca concentrar el poder de Jesús, de Pedro y de Roma)

Séptimo: la Iglesia, finalmente, sustituye al Imperio Romano occidental.

Ella asume las tareas que el Imperio ya no es capaz de cumplir (como ejemplo: Gregorio el Grande, Papa en Roma entre los años 590-604).

Cuanto más crecía el poder imperial del "Sumo Pontífice", más se aceleraba el proceso de su descomposición y desaparición. Solo la muerte de la Cristiandad Imperial Romana hará posible el nacimiento de la Iglesia (Richard: 1982).

\section{Reforma y Contra-reforma en la Iglesia católica}

En los inicios del siglo 16 surge una propuesta de reforma de la Iglesia

El protagonista principal fue Martín Lutero (1483-1546). La reforma impulsó la traducción de la Biblia en lengua vernácula, para devolver la Biblia al Pueblo de Dios. En sus orígenes la reforma buscó la reconstrucción del cristianismo originario y atacó la corrupción dentro de la Iglesia y el poder político del Papa. 
Contra-reforma en el Concilio de Trento (1545-1563)

Nace un modelo de Iglesia romano y clerical. Los pilares de la Iglesia tridentina fueron el Papa en Roma, el obispo en su diócesis y el párroco en su parroquia. De los laicos no se habla. El gran triunfador del Concilio de Trento fue el Papa. El papado llegó a ser el centro político de Europa. La gran perdedora fue la Biblia que, de hecho, fue sustituida por el Catecismo Romano y la Doctrina dogmática que tiene su fundamento en el Credo nicenoconstantinopolitano del siglo IV .

La contra-reforma continuó en el Concilio Vaticano Primero (1869-70). Fue un concilio eminentemente europeo, donde la Iglesia católica se sentía amenazada por la "civilización moderna". Se define la Iglesia como una "sociedad verdadera, perfecta, espiritual y sobrenatural", "la Iglesia es una sociedad visible y única, y fuera de la Iglesia no hay salvación". También se propusieron temas más políticos, como el poder de la Iglesia, el primado del Romano Pontífice, la soberanía temporal de la Santa Sede y la infalibilidad de la Iglesia y del Papa
Después de cuatrocientos años de contrarreforma tenemos un tiempo oportuno ("kairós") para una reforma de la Iglesia

Entre el fin del Concilio a Trento (1563) y los inicios del Concilio Vaticano II (1962) la Iglesia universal vivió cuatrocientos años con una orientación fundamental de contrarreforma. Durante 400 años en la Iglesia católica el Pueblo de Dios no tuvo acceso a la Biblia.

\section{El Concilio Vaticano II (1962-65) abre un nuevo período de reforma en la Iglesia}

Nace la nueva concepción de Iglesia como Pueblo de Dios, el Magisterio no se afirma por encima de la Palabra de Dios, sino a su servicio. Se transformó la liturgia de la Iglesia, en especial por el uso de las lenguas modernas. Se funda un nuevo ecumenismo entre las Iglesias cristianas. Se proponen todas las reformas necesarias para superar los 400 años de contra-reforma y re-orientar decididamente la Iglesia hacia un nueva reforma. 
Las conferencias generales del episcopado latinoamericano y caribeño (1955-2007)

Celebradas en Medellín (1968), Puebla (1979), Santo Domingo (1992) y la última en Aparecida (2007), retoman desde América Latina las reformas del Concilio Vaticano II. Entre el Concilio Vaticano II (1962-65) y la Conferencia de Puebla (1979) hay unos 20 años de reforma visible y significativa en la Iglesia latinoamericana y El Caribe; sin embargo, desde los años ochenta empieza a perfilarse una nueva corriente conservadora. El tiempo oportuno (Kairós) para una reforma de la Iglesia comienza a agotarse y la misma empieza lentamente a caminar hacia atrás, lo que está llevando a una crisis de la misma que esta vez podría transformarse en una crisis irreversible. Esta corriente conservadora coincide en gran medida con los 26 años del pontificado de Juan Pablo II (1978-2005), y ahora, desde el 2005, con el pontificado de Benedicto XVI.

La década de los ochenta fue especialmente agresiva con la Teología de la Liberación. La Congregación para la Doctrina de la Fe (dirigida entonces por el cardenal Ratzinger) publicó dos documentos condenando la Teología de la Liberación: Libertatis nuntius(1984) y Libertatis concientia
(1986). En el contexto militar, inspirado en la ideología de la Seguridad Nacional, la TL y toda la acción profética de la Iglesia fue desfigurada y perseguida. La consecuencia fue una multitud incontable de mártires. En 1989, con la caída de los "socialismos históricos", se proclamó "la muerte del comunismo, la muerte del marxismo y la muerte de la TL". En la década de los 80 , renace y se fortalece una Cristiandad, donde la Iglesia busca el poder, el dinero y la ley para sobrevivir, lo que encuentra en abundancia en los sectores millonarios y poderosos. Solo tres ejemplos: el "Opus Dei", los "Legionarios de Cristo", y finalmente los "Heraldos del Evangelio", que es una asociación privada de fieles de Derecho Pontificio. También se funda una "Sociedad Clerical" para los sacerdotes de los Heraldos. Su fundador es un Obispo de Sao Paulo, Brasil. Es una orden de corte feudal y militar, extremadamente conservadora y autoritaria. Todos estos "Legionarios" y "Heraldos" están al servicio del Sumo Pontífice para "salvar" la Iglesia del influjo de la "modernidad" y de toda corriente de "liberación". El proceso de contra-reforma ha llegado así a su máximo poder, pero también la Iglesia entra en una crisis que puede ser irreversible. 
Los orígenes del Cristianismo como memoria, credo y canon para una reforma actual de la Iglesia

Hemos buscado refutar dos posiciones negativas. Una, que niega la posibilidad de reconstruir la memoria de los orígenes del Movimiento Histórico de Jesús en sus primeros siglos. La otra, que niega la posibilidad de construir este Movimiento en la actualidad, con todas las diferencias históricas y geográficas evidentes. Rechazamos estas dos posiciones negativas y optamos por una memoria con esperanza.

Creemos que el Movimiento Histórico de Jesús, por lo menos en sus primeros 400 años, debe ser memoria, credo y canon para una reforma actual de la Iglesia. Si no sabemos hacia dónde vamos, por lo menos recuperemos la memoria que nos permite saber de dónde venimos. Queremos desafiar a una Iglesia que ha perdido la memoria de sus orígenes y en consecuencia ha perdido su identidad y capacidad para enfrentar en la actualidad una reforma profunda de sí misma.

Recordamos lo que nos dice Jesús al final del Sermón de la Montaña:

«Todo el que oiga estas palabras mías y las ponga en práctica, será como una persona prudente que edificó su casa sobre roca: cayó la lluvia, vinieron los torrentes, soplaron los vientos, y embistieron contra aquella casa; pero ella no cayó, porque estaba cimentada sobre roca. $Y$ todo el que oiga estas palabras mías y no las ponga en práctica, será como el hombre insensato que edificó su casa sobre arena: cayó la lluvia, vinieron los torrentes, soplaron los vientos, irrumpieron contra aquella casa y cayó y fue grande su ruina.»

Y sucedió que cuando acabó Jesús estos discursos, la gente quedaba asombrada de su doctrina; porque les enseñaba como quien tiene autoridad, y no como sus escribas". (Mateo 7, 21-29)

No partimos de cero. Hemos iniciado ya un nuevo modelo de Iglesia construido sobre roca. Es posible que vengan crisis profundas, y quizá irreversibles; la crisis puede estar ya a la puerta y puede acelerarse, incluso es posible un repentino "derrumbe" dentro de la estructura actual de la Iglesia. Nuestra esperanza es que una Iglesia, que se va construyendo sobre roca, no caerá. Aproximadamente, en los últimos cincuenta años, la Iglesia en Latinoamérica y el Caribe ha vivido un proceso de reforma y ha creado un modelo de Iglesia construido sobre roca. El modelo de Iglesia tradicional, por el contrario, está en gran medida construido sobre arena. 
En la memoria que hicimos de la Iglesia, especialmente durante los siglos IV y V, definimos el modelo de Iglesia de Cristiandad, como un modelo donde se une el poder "sagrado" con el poder económico y social. Este modelo necesita el poder, el dinero, la institución y la ley para sobrevivir. El nuevo modelo de Iglesia que buscamos construir es aquel que los pobres y oprimidos necesitan para sobrevivir. La referencia no es el poder económico y social, sino la vida de los pobres. Tal vez no exista hoy el optimismo y entusiasmo de las décadas pasadas, por eso recordamos las palabras de San Alberto Hurtado: "Cuando se te acabe el entusiasmo agárrate de la fe". Creo que ha llegado la hora de la fe.

\section{Fundamentos de la Iglesia construida sobre roca}

\section{La opción preferencial por los pobres (OPP)}

Marginados, excluidos, desechables e invisibles. La OPP es la opción por los pobres como sujetos capaces de luchar contra la pobreza y de construir alternativas. La OPP es también la opción por los excluidos por razones de género, etnia, raza, cultura, generación y opción sexual. Finalmente, es la opción por la tierra y el agua, cuyo grito ya no podemos ignorar. Esta opción es social y ética, pero también constitutiva de un nuevo modelo de Iglesia, con una cristología y eclesiología diferente. Así lo afirma la V Conferencia de Aparecida (Brasil 2007):

"La opción preferencial por los pobres es uno de los rasgos que marca la fisonomía de la Iglesia latinoamericana y caribeña” (391).

"Nuestra fe proclama que "Jesucristo es el rostro humano de Dios y el rostro divino del hombre" (392). "Los rostros sufrientes de los pobres son rostros sufrientes de Cristo". "Todo lo que tenga que ver con Cristo, tiene que ver con los pobres y todo lo relacionado con los pobres reclama a Jesucristo" (393).

\section{La lectura Comunitaria, Pastoral, Popular y Orante de la Biblia}

El movimiento bíblico ha buscado poner la Biblia en las manos, el corazón y la mente del Pueblo de Dios; busca devolver la Biblia al Pueblo de Dios y transformarlo en sujeto preferencial de su interpretación. Un paso superior es la "Lectura Orante de la Biblia" ("Lectio Divina") que transforma el texto bíblico en Palabra de Dios. Toda reforma de la Iglesia normalmente ha comenzado con un movimiento bíblico, donde la Palabra de Dios es fuente de autoridad, legitimidad, autonomía, libertad y creatividad. La Biblia nos revela la Palabra de Dios, pero también nos 
revela donde Dios se revela en el Libro de la Vida:

"La Biblia, el segundo libro de Dios, fue escrita para ayudarnos a descifrar el mundo, para devolvernos la mirada de la fe y de la contemplación, y para transformar toda la realidad en una gran revelación de Dios". (San Agustín: 354430 d.C.)

\section{Ética de la vida y espiritualidad liberadora}

La ética de la vida considera que lo único bueno, justo, verdadero y bello es que todos y todas, incluidas la tierra y el agua, tengan vida y vida en abundancia (Jn. 10, 10). La vida en concreto es trabajo, tierra, agua, salud, educación, celebración y participación para todos y todas. La Iglesia, que opta por la vida, opta por una sociedad donde quepan todos y todas, en armonía con la naturaleza; una Iglesia que cree que otro mundo posible. La ética de la vida es antagónica a la "ética" del mercado, cuyos valores son la codicia y la ganancia. Podemos resumir la ética cristiana en una famosa frase de San Irineo:

"La Gloria de Dios es el ser humano vivo, la gloria del ser humano es la visión de Dios" ("Gloria Dei vivens homo, vita autem hominis visio Dei"), San Ireneo, Contra los Herejes, libro $I V, 20.7))$.

\section{La Teología de la Liberación (TL)}

La TL es el "acto segundo" de una práctica que es "acto primero". La TL nace de la búsqueda de Dios al interior de una práctica de liberación. La TL no es solo una teoría o una escuela teológica, sino una nueva manera de hacer teología. La TL es una teología profética, que ha inspirado la Opción por los pobres, la Lectura Comunitaria de la Biblia y las Comunidades Eclesiales de Base; por eso es la Teología de una Iglesia construida sobre roca. Ella es ya una teología consolidada en América Latina y el Caribe, dentro y fuera de la Iglesia. Mientras haya pobres y oprimidos, y gente que crea en el Reino de Dios y en otro mundo posible, habrá TL.

\section{Las Comunidades Eclesiales de Base (CEB)}

Medellín reconoció en ellas una célula inicial de estructuración eclesial y foco de fe y evangelización. Puebla constató que... "las comunidades eclesiales de base permitieron al pueblo acceder a un conocimiento mayor de la Palabra de Dios, al compromiso social en nombre del Evangelio, al surgimiento de nuevos servicios laicales y a la educación de la fe de los adultos" (Así lo recuerda Aparecida n. 178).

La CEB es una pequeña comunidad, normalmente de gente 
pobre, que ora y medita la Palabra de Dios y practica la solidaridad. Su importancia no es tanto cuantitativa (su número), sino cualitativa (su manera nueva de ser Iglesia). La CEB es el fundamento de un nuevo modelo de Iglesia, opuesto al modelo de Cristiandad. Por eso las CEB crecen con fuerza propia, y no con el poder del dinero o de la institución. Son la base de la Iglesia que se va construyendo sobre roca.

Las CEB, con sus nuevas estructuras y nuevos ministerios, rompe la estructura piramidal y autoritaria de Iglesia y construye una Iglesia Pueblo de Dios, donde la autoridad no está "arriba", sino en el "corazón" del Pueblo de Dios; una Iglesia Comunión de Comunidades, donde la autoridad está en el centro mismo de la comunidad.

\section{Conclusión}

La reforma de la Iglesia que hemos vivido en los últimos 50 años $(1960$ - 2010) ha comenzado a desgastarse y agotarse, incluso estamos entrando en una crisis, quizás irreversible, de la Iglesia. La Iglesia ha comenzado lentamente a "caminar hacia atrás", dejando un "vacío profético" cada día más evidente.
Quisiéramos terminar con

una cita libre del teólogo José Comblin:

“...en muchas personas hay un gran desconcierto por la situación actual de la Iglesia. Una sensación de inseguridad. Cuando era joven yo conocí algo semejante $y$, tal vez, peor. Era el pontificado de Pì XII. Él había condenado a todos los teólogos importantes, había condenado todos los movimientos sociales importantes. Nosotros estábamos más que desconcertados, preguntándonos: ¿todavía hay porvenir? Hoy la situación de la iglesia Católica es igual a un castillo medieval, construido sobre una isla cercada de agua, levantaron el puente y tiraron las llaves al mar. La Iglesia está cortada del mundo, encerrada sobre si misma, sin ninguna posibilidad de realizar una reforma de sí misma". Más adelante Comblin nos dice "la cristiandad se está disolviendo progresivamente; el problema es después. De ahí la inseguridad, porque no sabemos lo que viene después. Esto sucedió muchas veces en la historia y todavía va a suceder probablemente muchas veces. Hay que aprender a resistir, a no dejarse desanimar o perder la esperanza por lo que sucederá" (San Salvador, en la celebración de los 30 años del martirio de Mons. Romero. José 
Comblin, el teólogo que más nos ha iluminado en este comienzo del tercer milenio, murió un año después, el 27 de marzo del 2011).

Es importante reconstruir un futuro con esperanza. El camino que hemos seguido ha sido recuperar la memoria de los primeros 500 años del Cristianismo. Esa memoria de los orígenes será el canon y el credo para una reforma indispensable de la Iglesia en el futuro.

\section{Bibliografía}

Hoornaert, Eduardo. 1986, La Memoria del Pueblo Cristiano, Una historia de la Iglesia en los tres primeros siglos, Madrid, Ediciones Paulinas, 308 pp.

Hoornaert, Eduardo. 2008, Los Orígenes del Cristianismo (una lectura crítica), San José de Costa Rica, DEI, 197 pp.
Nolan, Albert. 1981, ¿Quién es este hombre? Jesús antes del Cristianismo, Santander, España, Editorial Sal Terrae, $232 \mathrm{pp}$.

Richard, Pablo. 1982, Morte das cristandades e nascimento da Igreja, São Paulo, Edições Paulinas, 253 pp.

Richard, Pablo. 1998, El Movimiento de Jesús antes de la Iglesia, una interpretación liberadora de los Hechos de los Apóstoles, Santander (España), Editorial Sal Terrae, $191 \mathrm{pp}$.

Richard, Pablo. 2009, Memoria del Movimiento Histórico de Jesús, desde sus origenes (años 30) hasta la crisis del Sacro Imperio Romano Cristiano (siglos $I V y$ V), San José de Costa Rica, DEI, 398 pp.

Sobrino, Jon. 1997, Jesucristo Liberador, Lectura histórica teológica de Jesús de Nazaret, Madrid, Editorial Trotta, $350 \mathrm{pp}$.

Sotomayor, Manuel y Fernández, José (coordinadores). 2006, Madrid, Editorial Trotta, $943 \mathrm{pp}$. 
